\title{
Perbandingan Uji Hemostasis pada Preeklamsia Antara Awitan Dini dengan Awitan Lambat
}

\author{
Aisah Djumadisstsaniah ${ }^{1}$, Yusrawati ${ }^{2}$, Andi Friadi ${ }^{2}$ \\ ${ }^{1}$ Profesi Dokter Fakultas Kedokteran Universitas Andalas \\ ${ }^{2}$ Bagian Obstetri dan Ginekologi Universitas Andalas \\ Korepondensi: Aisah Djumadisstsaniah Email: aisahdj06@gmail.com
}

\begin{abstract}
Abstrak
Tujuan: Penelitian ini bertujuan untuk mengetahui perbandingan uji hemostasis pada preeklamsia antara awitan dini (PEAD) dengan awitan lambat (PEAL)

Metode: Penelitian ini adalah penelitian analitik observasional dengan pendekatan potong lintang dengan menggunakan data rekam medis pasien preeklamsia yang dirawat dan atau melahirkan di RSUP DR M Djamil Padang. Analisis univariate disajikan dalam bentuk tabel distribusi frekuensi dan analisis univariate menggunakan uji T tidak berpasangan dan uji Mann-Whitney

Hasil: PT (Prothrombine Time) dan APTT (Activated Partial Thromboplastin Time) lebih rendah pada PEAD daripada PEAL ( $p>0,05)$, D-dimer lebih tinggi PEAD daripada PEAL $(\mathrm{p}>0,05)$, dan jumlah trombosit lebih rendah PEAD daripada PEAL $(\mathrm{p}<0,05)$

Kesimpulan: Pada penelitian ini tidak terdapat perbedaan yang bermakna dari parameter faal pembekuan darah berupa PT, APTT, dan D-dimer, tetapi terdapat perbedaan yang bermakna pada jumlah trombosit antara PEAD dan PEAL dengan jumlah trombosit PEAD lebih rendah daripada PEAL
\end{abstract}

Kata kunci: Prothrombine time, activated partial thromboplatin time, D-dimer, jumlah trombosit, preeklamsia awitan dini dan awitan lambat

\section{Comparison of Hemostatic Test Result Between Cases of Early and Late Onset Preeclampsia}

\begin{abstract}
Objective: This study aimed to compare haemostatic test of early onset preeclampsia and late onset preeclampsia Methods: This study was observational analytic study using cross-sectional design that collected data from medical records patients of preeclampsia who were hospitalized and/or giving birth in RSUP DR M Djamil Padang. Data were analized using Univariate analysis were presented in the form of frequency distribution table and Bivariate data were tested with Independent T-Test and Mann-Whitney Test

Result: In this study, there was no differences in prothrombin time, activated partial thromboplastine time and D-dimer

but thrombocyte count were different between early and late onset Preeclampsia

Conclusion: On this research thrombocyte count is lower in early than late onset Preeclampsia and there is significantly different between early and late onset Preeclampsia
\end{abstract}

Key words: prothrombin time, activated partial thromboplastin time, D-dimer, thrombocyte count, early and late onset preeclampsia 


\section{Pendahuluan}

Kematian ibu menurut WHO (World Helath Organization) adalah kematian selama kehamilan atau pada 42 hari setelah berakhirnya kehamilan yang diakibatkan oleh semua sebab yang terkait atau diperberat oleh kehamilan ataupun penanganannya, dan bukan disebabkan oleh kecelakaan atau cedera. ${ }^{1}$ Menurut WHO tahun 2015 setiap hari terjadi sekitar 830 kematian ibu. ${ }^{2}$

Ada tiga penyebab utama kematian ibu di Indonesia yaitu perdarahan, hipertensi dalam kehamilan, dan infeksi. Preeklamsia menempati posisi kedua penyebab utama kematian ibu dan angkanya terus meningkat. $^{3}$

Angka kematian ibu berdasarkan Dinas Kesehatan Provinsi Sumatra Barat tahun 2014 sebesar 126/100.000 kelahiran hidup. ${ }^{4}$

Preeklamsia merupakan suatu sindrom khusus kehamilan dengan gejala meningkatnya tekanan darah $\geq 140 / 90$ $\mathrm{mmHg}$ yang disertai proteinuria $\geq 300$ $\mathrm{mg} / 24$ jam atau $\geq+1$ pada pemeriksaan dipstik pada usia kehamilan diatas 20 minggu. ${ }^{5}$ Berdasarkan onset terjadinya, preeklamsia dibagi menjadi preeklamsia awitan dini (PEAD) yang terjadi sebelum usia kehamilan 34 minggu dan preekamsia awitan lambat (PEAL) yang terjadi setelah usia kehamilan 34 minggu. Jumlah kejadian preeklamsia di RSUP Dr. M. Djamil Padang meningkat. Pada tahun 2014 terdapat 30 pasien, 2015 adalah 45 pasien, 2016 jumlahnya 81 pasien, dan 2017 adalah 144 pasien. ${ }^{6}$ Preeklamsia mempunyai beberapa teori, salah satunya adalah kerusakan endotel yang dapat menimbulkan berbagai kerusakan organ dan menimbulkan mortalitas dan morbiditas bagi ibu hamil dan juga janinnya. Preeklamsia awitan dini dikaitkan dengan adanya invasi trofoblas yang tidak adekuat dan dihubungkan dengan jalur plasental yang mengakibatkan prognosis preeklamsia awitan dini lebih buruk daripada awitan lambat. ${ }^{7}$ Perjalanan penyakit preeklamsia dapat berlanjut menjadi suatu komplikasi pada maternal dan fetal. Komplikasi pada fetal berupa IUGR (Intrauterin Growth Restriction), solusio plasenta, prematuritas, sindroma distres napas, dan kematian janin dalam rahim. Komplikasi pada maternal berupa sindroma HELLP (Haemolysis, Elevated Enzyme, Low Platelet), DIC (Disseminated Intravascular Coagulation), edem paru, gagal ginjal akut, dan trombositopenia. ${ }^{8}$ Salah satu komplikasi pada maternal adalah DIC, yaitu keadaan sistem koagulasi dan fibrinolitik teraktivasi secara sitematik dan kemudian mengakibatkan koagulasi intravaskular yang luas dan juga melebihi mekanisme antikoagulan yang alamiah. ${ }^{9}$ Keadaan koagulasi intravaskular diseminata ini diamati berasal dari perubahan spesifik pada faktor koagulasi atau fibrinolisis pada preeklamsia seperti penurunan jumlah trombosit dalam darah, antitrombin III, plasminogen, a2-antiplasmin, dan peningkatan fibrinogen degradation product (FDP). Pemeriksaan hemostasis rutin yang biasa digunakan adalah jumlah trombosit, masa protrombin (prothrombin time/PT), masa tromboplastin parsial teraktivasi (activated partial thromboplastin time/APTT), D-dimer, antri trombin III, dan fibrinogen. DIC merupakah suatu penyakit yang berhubungan dengan koaguasi pada hemostasis dan juga perlu menilai perubahan faktor hemostasis yang terjadi pada preekelamsia awitan dini dan awitan lambat.

Pada Preeklamsia terjadi gangguan mikrovaskular dan kerusakan endotel. Pada preeklamsia awitan lambat gangguan mikrovaskular lebih lama dan dapat terjadi gangguan organ salah satunya gangguan fungsi hepar yang dapat memungkinkan terjadinya gangguan pembekuan darah khususnya pada jalur intrinsik. Perubahan keadaan faal pembekuan darah dapat diukur 
dengan menggunakan uji hemostasis berupa PT, APTT, D-dimer, dan jumlah trombosit. Pada penelitian lain juga membandingkan faal pembekuan darah dengan menilai rerata PT, APTT, D-dimer, dan jumlah trombosit. pada PEB, eklamsia, dan kehamilan normal. ${ }^{10}$ Berdasarkan latar belakang diatas maka penulis tertarik meneliti perbandingan jumlah trombosit, PT, APTT, dan D-dimer pada preeklamsia antara awitan dini dengan awitan lambat yang dirawat dan atau melahirkan di RSUP DR. M. Djamil Padang.

\section{Metode}

Jenis penelitian yang digunakan adalah analitik observasional dengan pendekatan cross sectional dengan menggunakan data rekam medik di RSUP dr. M. Djamil Padang. Variabel independen adalah awitan preeklamsia dan variabel dependen PT, APTT, D-dimer, dan jumlah trombosit. Penelitian dilakukan dari Desember 2018 - Februari 2019 di bagian rekam medik RSUP Dr. M. Djamil Padang.

Populasi penelitian ini adalah seluruh pasien ibu hamil yang dirawat dan melahirkan dengan preeklamsia sesuai dengan kriteria meningkatnya tekanan darah $\geq 140 / 90 \mathrm{mmHg}$ dan disertai proteinuria $\geq 300 \mathrm{mg} / 24 \mathrm{jam}$ atau $\geq+1$ pada pemeriksaan dipstik pada usia kehamilan diatas 20 minggu di bagian Obgyn RSUP DR M Djamil Padang periode 31 Desember 2017 sampai dengan jumlah sampel terpenuhi.

Sampel penelitian yang dipilih adalah data rekam medik yang memenuhi kriteria inklusi dan ekslusi. Kriteria inklusi: Ibu hamil dengan preeklamsia yang dirawat dan atau melahirkan di RSUP DR M Djamil Padang dan dengan data rekam medis yang lengkap.

Kriteria eksklusi: IUFD (Intrauterine Fetal Death).

Jumlah sampel yang dibutuhkan adalah 134 sampel. Teknik pengambilan sampel yang digunakan adalah consecutive sampling. Data dianalisis secara statistik berdasarkan variabel yang dinilai menggunakan sistem komputerisasi yaitu analisis univariat dan bivariat. Analisis univariat dilakukan untuk mengetahui karkteristerik preeklamsia awitan dini dan awitan lambat. Analisis bivariat dilakukan untuk untuk mencari perbandingan dua variabel, yaitu PT, APTT, D-dimer, dan jumlah trombosit dengan PEAD dan PEAL di RSUP DR M Djamil Padang. Data dianalisis dengan uji t-test tidak berpasangan dan uji Mann-Whitney. Korelasi dinyatakan bermakna jika didapatkan nilai $\mathrm{p}<0,05$.

\section{Hasil}

Penelitian ini menggunakan rekam medis pasien preeklamsia di RSUP Dr. M. Djamil Padang yang memenuhi kriteria inklusi dan eksklusi. Jumlah sampel yang digunakan adalah 134. Pada analisis univariat didapatkan karakteristik berupa distribusi frekuensi.

Usia kedua kelompok ditemukan paling banyak pada interval 31-40 tahun. Tekanan darah sistol dan diastole pada kedua kelompok didapatkan rerata yang hampir sama antara PEAD dan PEAL Paritas didapatkan lebih banyak multipara daripada nulipara pada PEAD dan PEAL. Kadar rerata enzim hati SGOT dan SGPT lebih tinggi pada PEAD daripada PEAL. Rerata LDh lebih tinggi pada PEAD daripada PEAL. Peningkatan LDH dapat mengindikasikan dampak pada hati dan gangguan hemolisis. Hemolisis, peningkatan enzim hati, penurunan jumlah trombosit, dan adanya gejala klinis yang timbul merupakan suatu sindrom pada preeklamsia yang disebut sebagai sindroma HELLP.

enurunan jumlah trombosit, dan adanya gejala klinis yang timbul merupakan suatu sindrom pada preeklamsia yang disebut sebagai sindroma HELLP. 
Tabel 1 Karakteristik Subjek

\begin{tabular}{lcccccc}
\hline & \multicolumn{3}{c}{ PEAD (n=67) } & \multicolumn{3}{c}{ PEAL (n=67) } \\
\cline { 2 - 6 } & $\mathbf{n}(\%)$ & Rerata \pm SD & $\begin{array}{c}\text { Med } \\
\text { (Min-Maks) }\end{array}$ & n(\%) & Rerata \pm SD & $\begin{array}{c}\text { Med } \\
\text { (Min-Maks) }\end{array}$ \\
\cline { 2 - 6 } Usia (th) & $67(100 \%)$ & $32,4 \pm 6,4$ & & $67(100 \%)$ & $32,4 \pm 7,5$ & \\
$11-20$ & $4(5 \%)$ & & & $8(12 \%)$ & & \\
$21-30$ & $17(26 \%)$ & & $14(21 \%)$ & & \\
$31-40$ & $42(64 \%)$ & & $35(53 \%)$ & & \\
$41-50$ & $4(5 \%)$ & & $10(14 \%)$ & & \\
Paritas & & & & $17(25 \%)$ & & \\
Nulipara & $13(19 \%)$ & & $50(75 \%)$ & & $171,49 \pm 18,02$ & $170(140-220)$ \\
Multipara & $54(81 \%)$ & & & $106,94 \pm 12,85$ & $100(80-150)$ \\
Sistol $(\mathrm{mmHg})$ & & $176,3 \pm 21,9$ & $170(130-235)$ & & $34,1 \pm 36,2$ & $23(12-248)$ \\
Diastol $(\mathrm{mmHg})$ & & $109,8 \pm 16,8$ & $100(80-160)$ & & $19,7 \pm 22,6$ & $12(4-112)$ \\
SGOT $(\mu / \mathrm{l})$ & & $111,4 \pm 285,7$ & $33(11-2230)$ & & $525,8 \pm 224,7$ & $497(259-1616)$ \\
SGPT $(\mu / \mathrm{l})$ & & $60,72 \pm 104,2$ & $20(4-729)$ & & $8,3 \pm 0,6$ & $8,3(7,2-9,9)$ \\
LDH $(\mu / \mathrm{l})$ & & $998 \pm 920$ & $694(259-6165)$ & & \\
Ca $(\mathrm{mg} / \mathrm{dL})$ & & $7,8 \pm 0,82$ & $7,8(6,3-11,6)$ & & & \\
\hline
\end{tabular}

Tabel 2 Perbandingan Uji Hemostasis

\begin{tabular}{llcccc}
\hline \multirow{2}{*}{$\begin{array}{c}\text { Uji } \\
\text { Hemostasis }\end{array}$} & \multicolumn{2}{c}{ PEAD $(\mathbf{n}=67)$} & \multicolumn{2}{c}{ PEAL $(\mathbf{n}=67)$} & P Value \\
\cline { 2 - 5 } & Rerata \pm SD & $\begin{array}{c}\text { Med } \\
\text { (Min-Max) }\end{array}$ & Rerata \pm SD & $\begin{array}{c}\text { Med } \\
\text { (Min-Max) }\end{array}$ & \\
\hline PT (detik) & $9,22 \pm 0,082$ & & $9,52 \pm 0,10$ & & $0,477^{\mathrm{a}}$ \\
APTT (detik) & $33,27 \pm 0,64$ & & $33,5 \pm 0,56$ & & $0,801^{\mathrm{a}}$ \\
D-dimer (mg/dL) & & $2,40(0,38-10)$ & & $1,79(0,51-10)$ & $0,140^{\mathrm{b}}$ \\
Trombosit $\left(/ \mathrm{mm}^{3}\right)$ & $2,03 \pm 1,37$ & & $2,70 \pm 1,17$ & & $0,000^{\mathrm{a}^{*}}$ \\
\hline
\end{tabular}

Keterangan: a: T-test tidak berpasangan, $\mathrm{b}$ : Mann-Whitney, ${ }^{*}: p$ value bermakna

Sebelum di uji perbedaannya, dilakukan uji normalitas dengan uji normalitas Kolmogorov-Smirnov terhadap data. Hasil uji normalitas memperlihatkan bahwa distribusi data normal pada PT, APTT, dan jumlah trombosit dan tidak normal pada D-dimer.

Uji T-test tidak berpasangan pada PT dan APTT lebih rendah PEAD daripada PEAL pada pasien preeklamsia di RSUP DR M Djamil Padang tidak terdapat perbedaan yang signifikan $(\mathrm{p}>0,05)$. Uji Mann-Whitney pada D-dimer lebih tinggi pada PEAD daripada PEAL dan tidak terdapat perbedaan yang signifikan $(p>0,05)$. Uji T-test tidak berpasangan pada jumlah trombosit lebih rendah PEAD daripada PEAL dan terrdapat perbedaan yang signifikan $(p<0,05)$.

\section{Pembahasan}

\section{Karakteristik Subjek}

Penelitian ini dilakukan terhadap 134 pasien preeklamsia yang dirawat dan atau melahirkan di RSUP Dr. M. Djamil Padang. Ibu dengan usia yang lebih tinggi lebih rentang terkena penyakit degeneratif. ${ }^{11}$ Tekanan darah sistol dan diastol sejalan dengan penelitian lain tekanan darah sistol dan diastol memiliki nilai rentan yang tidak begitu jauh. ${ }^{12}$ Multiparitas menjadi risiko 
dalam kehamilan dan berkaitan dengan peningkatan prevalensi komplikasi pada ibu dan bayi baru lahir. ${ }^{13}$ Preeklamsia juga dapat menyebabkan perdarahan sel periportal lobus perifer yang akan membuat berkurangnya aliran darah ke sel hepar dan terjadinya peningkatan ezim hepar. ${ }^{14}$ Sindroma HELLP merupakan salah satu komplikasi maternal yang dapat terjadi pada preeklamsia. ${ }^{15}$ Rerata kadar kalsium lebih rendah pada PEAD daripada PEAL. Kalsium diperlukan pada proses koaguasi pada jalur ekstrinsik maupun intrinsik. ${ }^{16}$

\section{Perbandingan Uji Hemostasis}

Penelitian ini mendapatkan perbedaan yang signifikan pada jumlah trombosit antara PEAD dan PEAL $(p<0,05)$. Perbandingan uji hemostasis PT tidak ditemukan perbedaan yang signifikan pada uji statistik. Rerata PT PEAD dan PEAL relatif normal dan rerata PEAL lebih tinggi daripada PEAD.Hasil ini sejalan dengan penelitian lain di China yang mendapatkan tidak terdapat perbedaan PT pada PEB PEAD dan PEAL dan rerata PT PEAL lebih tinggi daripada PEAD dan masih dalam rentang normal. ${ }^{17}$ Pada penelitian nilai PT pada PEALlebih tinggi daripada PEAD hal ini dapat disebabkan karena pada PEAD dan PEAL tidak terdapat abrupsio plasenta atau IUFD yang dapat membuat PT memanjang. Oleh sebab itu PT akan mengikuti arah nilai kehamilan dengan preeklamsia sesuai usia kehamilan..

Perbandingan uji hemostasis APTT tidak menunjukan perbedaan yang bermakna dengan rerata APTT pada PEAD dan PEAL relatif normal dan PEAL lebih tinggi daripada PEAD. Pada penelitian Jing membandingkan Preeklamsia berat awitan dini dan awitan lambat tidak terdapat perbedaan yang signifikan pada nilai APTT pada kedua kelompok dan rerata APTT PEAD lebih tinggi daripada PEAL. ${ }^{17}$ Pada penelitian lain yang dilakukan di China tidak terdapat perbedaan APTT pada PEB PEAD dan PEAL dengan rerata APTT PEAL lebih tinggi daripada PEAD. ${ }^{18}$

Perbandingan nilai D-dimer tidak menunjukan perbedaan yang bemakna dengan D-dimer pada PEAD lebih tinggi daripada PEAL. Pada penelitian lain yang membandingan D-dimer pada PEAD dan PEAL terdapat perbedaan yang signifikan dan ditemukan rerata nilai D-dimer PEAD lebih tinggi daripada PEAL. ${ }^{19}$ Peningkatan konsentrasi D-dimer menggambarkan keparahan penyakit dan aktivasi trombosit yang mengindikasikan substansial dalam pengaktifan sistem fibrinolitik. ${ }^{20}$ Durasi dan keparahan preeklamsia juga dapat mempengaruhi nilai d-dimer karena PEAD durasi terjadinya preeklamsia lebih awal maka gangguan lebih awal akan memperburuk keadaan dan nilai D-dimer akan meningkat pada pasien PEAD.

Perbandingan rerata jumlah trombosit menunjukan perbedaan yang bermakna dengan rerata PEAD lebih rendah daripada PEAL. Pada penelitian lain ditemukan perbedaan yang signifikan pada jumlah trombosit PEAD dan PEAL dengan rerata nilai PEAD lebih rendah daripada PEAL. ${ }^{21}$

Penurunan jumlah trombosit bervariasi dipengaruhi oleh keparahan, durasi, dan cara hitung trombosit. Semakin lama durasi preeklamsia akan memperburuk kerusakan endotel vaskular yang akam menyebabkan aktivasi trombosit dan agregasi trombosit sehingga terjadi penurunan jumlah trombosit.

Berdasarkan hasil penelitian ini didapatkan kesimpulan bahwa tidak terdapat perbedaan yang bermakna dari parameter faal pembekuan darah yaitu uji hemostasis PT,APTT, dan D-dimer dengan nilai PT dan APTT lebih tinggi pada PEAD daripada PEAL dan D-dimer lebih tinggi PEAD daripada PEAL, tetapi terdapat perbedaan yang bermakna pada jumlah trombosit dengan jumlah trombosit PEAD lebih rendah daripada PEAL. 


\section{Saran}

Untuk penelitian selanjutnya disarankan agar menilai perbandingan uji hemostasis pada preeklamsia antara awitan dini dengan awitan lambat yang dilakukan dengan metode kohort dengan pemantauan antenatal care agar pertama kali terdiagnosis awitan preeklamsia lebih akurat. Kemudian, penelitian selanjutnya sebaiknya dilakukan dengan menambahkan faktor pembekuan lain yang berkaitan dengan kalsium darah.

\section{Daftar Pustaka}

1. World Health Organization (WHO). Maternal Mortality in 2005: Estimates Developed by WHO, UNICEF, UNFPA, and the Wolrd Bank. Bull World Heal Organ. 2007;79:657-64

2. World Health Organization (WHO). Maternal Mortality in 2015. (Diakses 5 November 2017). Tersedia dari: http:// www.who.int/gho/maternal_health/ mortality/maternal_mortality_text/en/

3. Pusat Data dan Informasi Kementrian Kesehatan RI. 2014.(Diakses 4 Januari 2018). Tersedia dari: http://www.depkes. go.id/resources/download/pusdatin/ infodatin/infodatin-ibu.pdf

4. Dinas Kesehatan Provinsi Sumatra Barat. Profil Dinas Kesehatan Provinsi Sumatra Barat 2014. (Diakses 18 Desember 2017). http://www.depkes.go.id/resources/ download/profil/PROFIL_KES PROVINSI_2014/03_Sumatera\%20 Barat_2014.pdf

5. Cunningham FG. Obstetri Williams. Setia $\mathrm{R}$, editor (penyunting). Hipertensi dalam Kehamilan. Edisi ke-23 Jakarta: EGC; 2012: 742-71

6. Instalasi Rekam Medik RSUP Dr. M. Djamil Padang. Data rekam medik preeklamsia tahun 2017 bagian rawat jalan dan rawat inap. Padang: RSUP Dr.
M. Djamil;2017.

7. Gulec UK, Ozgunen FT, Buyukkurt S, Guzel AB, Urunsak IF, Demir SC, et al. Comparison of clinical and Laboratory Findings in Early- and Late-Onset Preeclampsia. J. Matern Fetal Neonatal Medicine. 2013;26(12):1228-33.

8. Prawirohardjo S. Ilmu Kebidanan. 4th ed. Jakarta: PT. Bina Pustaka Sarwono Prawirohardjo; 2013:550

9. Sudoyo AW, Setiyohadi B, Alwi I, Simadibrata M, Setiati S. Buku Ajar Ilmu Penyakit Dalam Jilid II edisi V. Koagulasi Intravaskular Diseminata. Jakarta: Interna Publishing; 2009: 777-79

10. Sofyan Y, Serudji J, Bachtiar H. Perbedaan Rerata Faktor Hemostasis Pada PEB, Eklamsia, dan Kehamilan Normal. Jurnal OBGIN EMAS. 2015 Jan-April;1:(32): 27-34

11. Lamminpaa R, Vehvilaeinen-Julkunen K, Gissler M, Heinonen S. Preeclampsia Complicated by Advance Maternal Age: A Registry-based Study on Primiparous Women in Finland 1997-2008. BMC Pregnancy Childbirth. 2012; 12(1): 47

12. Aziz A, Mose JC. The Differences of Characteristic, Management Maternal and Perinatal Outcomes Among Early and Late Onset Preeclamsia. Open Acces Library Journal. 2016; 3(6): 1-7

13. Mgaya AH, Massawa SN, Kidanto HL, Mgaya HN. Grand Multiparity: Is It Still a Risk in Pregnancy?. BMC Pregnancy Childbirth. 2013; 13(1): 241

14. Bozdağ H, Öğütcüoğlu FB, Akdeniz DE, Kabaca KSR, Topdağı Aİ, Gökdağı F, et la. The Frequency and Fetomaternal Outcomes of Early- and Late-Onset Preeclampsia: The Experience of a Single Tertiary Health Centre in The Bustling Metropolis of Turkey; Istanbul. Medeniyet Medical Journal. 2015;30(4): 163-69

15. Jaiswar SP, Amrit G, Rekha S, Natu SN, Mohan S. Lactic Dehydrogenase: A 
Biochemical Marker For PreeclampsiaEclampsia. Journal of Obstetry and Gynecology India. 2011;61(6):645-8

16. Hall JE, Guyton AC. Buku Ajar Fisiologi Kedokteran. 9th ed. Irawati $\mathrm{S}$, editor. Hemostasis dan Pembekuan Darah. Jakarta: EGC; 2014:437-92

17. Shen J, MA Xiaoyan, Yi F, Rasul A, Cui M, MA Tonghui. Increased Expression Levels of Vitronectin In The MaternalFetal Interface of Placenta in EarlyOnset Severe Preeclampsia. Molecular Medicine Reports. 2013;7:53-58

18. Xin H, Wang HL. Expression Changes and Clinical Significance of Annexin V in Maternal Blood and Placenta in Patients With Preeclampsia. Zhonghua Fu Chan Ke Za Zhi. 2011; 46(2): 88-93

19. Boij R, Svensson J, Nillson EK, Sandholm $\mathrm{K}$, Lindahl T, Palonet E, et al. Biomarkers of Coagulation, Inflammation, and
Agiogenesis are Independently Associated With Preeclampsia. American Journal of Reproductive Immunology. 2012;68(3):258-70

20. Heilmann L, Rath W, Pollow K. Hemostatic Abnormalities In Patients With Severe Preeclampsia. Clinical and Applied Thrombosis/Haemostasis. 2017; 13(3): 285-91

21. Sari DK. Perbandingan Rerata Hitung Darah Lengkap Antara Preeklamsia Awitan Dini DanAwitan Lambat. (skripsi). Fakultas Kedokteran Universitas Andalas Kota Padang.2016. 